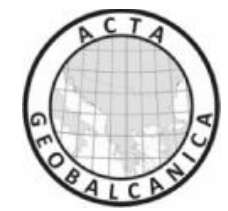

\title{
GEOGRAPHY OF THE NEW ELECTORAL SYSTEM AND CHANGING VOTING PATTERNS IN HUNGARY
}

\author{
Zoltán Kovács ${ }^{1}$ \\ György Vida ${ }^{2}$ \\ ${ }^{1}$ Department of Economic and Social Geography, University of Szeged and Institute of \\ Geography, Research Centre for Astronomy and Earth Sciences, Hungarian Academy of \\ Sciences, Hungary. \\ ${ }^{2}$ Department of Economic and Social Geography, University of Szeged, Hungary. \\ Corresponding author: zkovacs@iif.hu
}

\begin{abstract}
After nearly half a century of single-party communist dictatorship Hungary returned to a pluralist democratic system in 1989-1990. The electoral system that was designed hastily before the first postcommunist elections held in March 1990 remained intact for two decades. Combining geographical representation (single candidates) and proportional party representation (party-lists) according to the German model, it provided a solid basis for six consecutive parliamentary elections. However, due to demographic processes and migration the size of electoral districts became very much disproportionate already by the early 2000s. Nevertheless, the elaboration of a new electoral law became possible only after the landslide victory of Orbán's conservative party (FIDESZ) in 2010, with two-thirds majority in the Hungarian parliament. The new law was finally accepted by the house in November 2011. The mixed nature of the electoral system was kept, however, the total number of MPs was nearly halved, and the boundaries of the single member electoral districts were redrawn substantially. The new electoral system was tested in the parliamentary elections in April 2014. This paper provides an overview about the changes of the Hungarian electoral system and its consequences for political representation. Based on the results of the 2014 Hungarian parliamentary elections the paper also explores the geographical bias of the new Hungarian electoral system with special attention to malapportionment and partisan gerrymandering.
\end{abstract}

Keywords: electoral geography, Hungarian electoral system, geographical bias, voting patterns;

\section{INTRODUCTION}

Demographic shifts and migratory processes have caused growing imbalances in the size of electoral districts in Hungary since 1990. As size differences grew more and more people questioned the fairness of the electoral system, however, to change the electoral law and the electoral subdivision of Hungary a two-third majority in the parliament is needed. In the 2010 elections Viktor Orbán's conservative party (Fidesz) together with its close alliance the Christian Democratic People's Party (KDNP) celebrated a landslide victory and reached the threshold, thus, and electoral reform became legally possible. Act 203 of 2011 changed the system of elections in Hungary 
whereas Act 36 of 2013 set the new geographical framework of future elections substantially redrawing the boundaries of constituencies. Altogether the total number of MPs was reduced from 386 to 199 . The new electoral system was first tested in the parliamentary elections of April 2014 which provides a good opportunity to test the efficiency and justice of the new system.

The aim of this paper is twofold, on the one hand, we would like to test the disproportionality of the Hungarian electoral system due to size differences of constituencies, and also how it was changed after 2011 by the new law, and on the other hand we would also like to investigate the geographical features of the voting pattern in the 2014 elections in comparison with previous elections. Our methods fall to the mainstream of quantitative electoral geography, applying data both from the 2011 Hungarian census and the 2014 general elections, aggregated on the level of electoral districts. In addition to descriptive data we also use inductive statistics and Pearson correlation analysis. The paper is divided into five parts.

First we discuss briefly the concept of geographical bias in electoral geography based on the literature. In the second part we elucidate the geographical features of the Hungarian electoral system both before the reform and after. This is followed by a test on the equal population criterion of Hungarian constituencies after 2011. In the fourth chapter we turn the attention to the changes in voting pattern between the 2010 and 2014 elections. Finally, we provide a short conclusion.

\section{GEOGRAPHICAL BIAS AND THE ELECTORAL GEOGRAPHY}

Due to the interplay of different political, legal, social etc. factors there is no absolutely fair electoral system in the world, however, there is a consensus among experts that efforts should be made to reach the highest possible level of proportional representation. John Rawls [15] noted that political fairness is generally based upon the principles of freedom and participation. It requires that all citizens are to have an equal right to take part in the constitutional process that establishes the laws with which they are to comply. And this in turn requires single member territorial constituencies, that members of the legislature (with one vote each) represent the same number of electors [15]. In his work on justice Young [17] emphasised that not only proportionality, but also the effort to lower existing dispropotionality is important. According to Webster [16] justice is a complex and relative term and it is deeply rooted in the everyday practice of civil rights. In this process the emphasis should be placed on analysing the balance between advantages and disadvantages.

As it can be seen political justice and fair representation are often on the agenda among social scientist sustaining a wave of research on the justice of electoral systems. These studies tend to measure the disproportionality of electoral systems with different statistical methods (Loosemore-Hanby's Index, Gallagher Index) and its possible effects on the part system [4]. However, in these studies the geographical features of disproportionality are often neglected. According to Ron Johnston [6] in any electoral system where certain parts of seats are allocated in constituencies geography most precisely electoral geography has an important role.

Geographers dealing with electoral geography emphasize the need to focus on the question how votes are transformed into political representation, and in this respect the 
issue of apportionment or redistricting are inevitable to deal with [11], [3], [8], [16]. Research focuses most frequently on the questions, how effectively electoral systems translate the political wish of voters into parliamentary representation, on the one hand, and on the other how the boundaries of electoral districts are drawn, whether geographical bias (malapportionment, gerrymanderying) play a role [11]. In his seminal publication Johnston [6] defined six possible components of geographical bias in electoral districting (Figure 1).

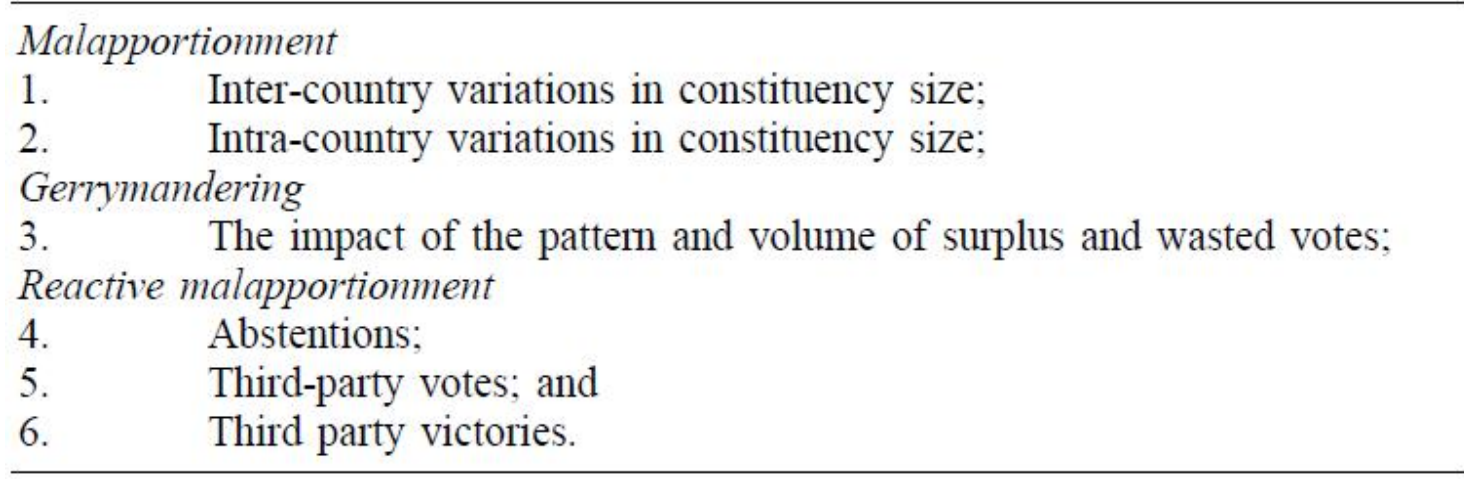

Figure 1. Six separate bias components by Ron Johnston

Source: Johnston, R. 2002

It can be noted that Johnston's model (which was also commented by Moore [14], Erikson [2], and Altman [1] in the same issue) is applicable mainly for the Plurality/Majority systems with two dominant parties in competition, like in the United States or United Kingdom. Even though Hungary has traditionally a mixed electoral system since 1990 a substantial part of the MPs are elected by single-member election districts, therefore, research methods of the Anglo-Saxon geography are also applicable here with certain modifications. Following Johnston's model we concentrate in this paper on two bias components malapportionment and abstentions in Hungary.

In addition to the constitutionally mandated equal population criterion in the AngloSaxon electoral geography seven additional principles became subjects of research, these are: racial equity, compactness, contiguity, preservation of local government subdivisions, preservation of communities of interest, preservation of the cores of prior districts, and the protection of incumbents [16]. These principles are often in conflicts with each other in practice and their interpretation can also differ in space and time.

\section{THE HUNGARIAN ELECTORAL SYSTEM AND ITS CHANGES AFTER 2011}

Act 34 of 1989 re-established multi-party democracy in Hungary after more than forty years of one party dictatorship. Regarding the elections a compromise between the concept of majority (single candidate) representation and proportional party representation was made [9]. In this respect the new post-communist electoral law is very similar to the German electoral system. After 1990 out of the 386 seats in the Hungarian parliament 176 were chosen in single-member districts, where successful candidates had to collect 750 endorsement sheets before the elections. The winner of constituency election had to receive 50 percent plus one vote in the first round. If no candidate received a majority in the first round all candidates receiving at least fifteen 
percent of the vote could go on to the second round. In the second round the candidate with the highest number of votes was elected [12].

Fifty-five percent of the 386 seats in the Hungarian parliament were chosen by way of proportional representation [10]. Only parties exceeding the 5 percent threshold (in 19904 percent) could gain parliamentary representation. Proportional election took place by way of two methods, county lists and national lists. In the county list process each registered political party could set up a list of candidates in the 19 counties and in Budapest if the party had at least two candidates in the single-member districts. The national party list was not directly voted by the electorate but by the 'scrap' (i.e. unused) votes of all the unsuccessful district party candidate and the party county lists. Thus, under these circumstances each voter was eligible to cast two votes one for a district candidate and another for a political party list [13].

Disproportionality of single-member districts was a problem in Hungary from the very beginning since the number of eligible voters was 2.25 times higher in the biggest constituency than the smallest one in 1990. However, due to demographic factors and migration (e.g. suburbanization) the difference between the biggest and smallest electoral district grew to 2.77 by 2010 [5]. Size differences among the counties also substantially increased which meant a challenge for the justice of the whole electoral system. Even though politicians realised the tensions caused by growing disproportionality of constituencies, due to the lack of consensus among leading political parties in the house no amendments were possible. After the 2010 elections, however, the centre-right Fidesz-KDNP coalition reached two-thirds majority in the parliament and an electoral reform became possible. Two subsequent acts, Act CCIII. of 2011 on the Elections of Members of Parliament and Act XXXVI. of 2013 on Electoral Procedure made a tabula rasa in the post-communist electoral system in Hungary substantially rewriting the rules and geographical frameworks of parliamentary representation.

The mixed system was kept, though the total number of seats in the Hungarian parliament was reduced from 386 to 199, out of which 106 are now elected in singlemember districts and 93 by party lists. Thus, the slight dominance of proportional representation of the earlier electoral system was shifted towards the majoritarian principle as MPs elected in single member districts now occupy 53.2 percent of the seats in the parliament. This means a certain threat in future election results to become even more disproportional when comparing mandate proportions in parliament to proportions of votes cast for party list. The two rounds balloting in single-member districts was changed to one round, thus, similarly to the British/US system single majority is enough to win the mandate of a constituency.

The way of proportional election was also changed, only national lists remained. Successful single candidates have to collect at least 1000 endorsement sheets. Only parties that are able to nominate at least 27 candidates in at least nine counties (including Budapest) can set up a national list. The 5 percent threshold for parliamentary representation remained intact. In addition several new rules were introduced regarding the electoral system and the electoral procedure in Hungary. One eligible voter can give endorsement sheet for more candidates. Smaller parties became unfavoured by the new law as 'scrap' votes also counts for the winners. Another essential feature of the new law is that ethnic Hungarians living in the neighbouring 
countries who obtained Hungarian citizenship are entitled to participate in the party-list balloting.

From a geographical point of view perhaps the most important question is how the boundaries of the new constituencies were drawn. According to the law each district has to contain roughly the same number of voters, with a maximum of 15 percent divergence from the mean value. In this respect the law more or less complies with the recommendation of the Venice Commission which is 10 percent. The enforcement of this rule actually marked a significant improvement over the existing situation, which the Constitutional Court ruled unconstitutional twice previously, to no avail. In addition there are two important criteria to be applied: districts have to adhere to existing county boundaries and district borders have to be contiguous. Later rules made absurd outcomes of re-districting, such as for example dragonshaped districts, unlikely.

As it can be seen out of the principles emphasised by Webster [16] the equal population criterion, compactness and contiguity became a cornerstone of the new law, however, the preservation of communities of interest and the protection of incumbents remained completely neglected. Formal criteria surpassed community interests regarding the redrawing of electoral district boundaries while malaportionment was coded in the new system of districts due to the rigid geographical boundaries (i.e. counties) forced by the law.

\section{THE EQUAL POPULATION CRITERION AFTER 2011}

To test the equal population criterion we made calculations on the convergence of single member districts to the national average based upon the 2011 national census, and the voters' registry of the 2014 elections. We should bear in mind that the law tolerate a maximum of 15 percent divergence from the mean value of population size calculated from all constituencies. The law also sets that if disproportionalities reoccur because of migration, resulting in a difference of 20 percent in the voter population of a district when compared to the mean, Parliament will have to amend the constituency boundaries accordingly.

Our findings show that there was a clear convergence among the single member districts compared to the national average after the boundaries were redrawn between the 2010 and 2014 elections. However, we could also find substantial differences among counties and constituencies embedded in the same county. There are too small and too large electoral districts where future population changes might create serious discrepancy (Figure 2). 


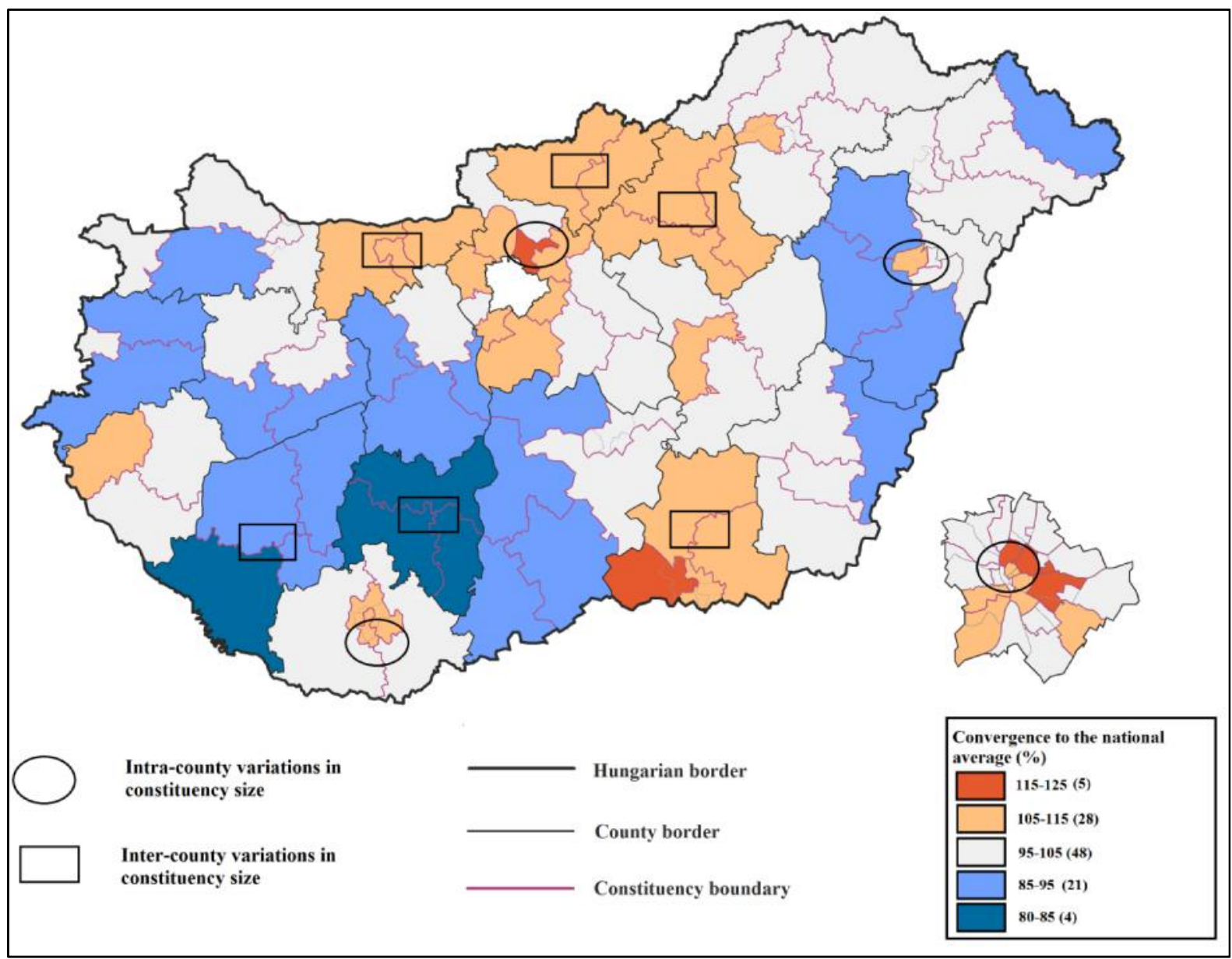

Figure 2. The level of convergence of the Hungarian single member districts to the national average based on the number of eligible voters in 2011

Source: Hungarian Statistical Office

The greatest challenge for redrawing the boundaries of electoral districts after 2010 was clearly the rule set by the new (and also the previous) law that county boundaries could not be crossed, i.e. all constituencies should be embedded in one county. Give the considerable differences among the counties regarding their population size this single rule caused a challenge for any geographical reconfiguration. At the same time counties are not homogeneous either as far as the geographical distribution of population is concerned. In the light of these two geographical handicaps it was really a hard task to redraw the boundaries of electoral districts after 2010 .

As society is not static in space over time it could also be expected that the boundaries redrawn in 2011 will distorted already by the 2014 elections. Our analysis on the data of voters' registry showed that the number of eligible voters already decreased in some of the inner-city constituencies in Budapest as well as in some rather peripheral electoral districts in the countryside by the 2014 elections, while in other (mainly suburban) constituencies a further slight increase was detected. Thus, growing disproportionality of electoral districts was shortly reproduced by territorial differences in demographic trends in the country.

Fair political representation is also distorted by abstentions as one of the forms of reactive malapportionment according to Johnston [6]. Our calculations showed weak 
positive Pearson correlation for the 2011 data, but this connectivity seems to be terminated by 2014 . In addition to the shrinkage of some of the Budapest constituencies the main reason behind is the growing turnout rates in Northern Hungary as an outcome of increasing rivalry among the political parties and the appearance of a 'third pole' (radical nationalist Jobbik, 'Movement for a Better Hungary') in the political spectrum. Thus, next to traditional malaportionment abstention played a subordinated role in the 2014 elections.

\section{CHANGING VOTING PATTERNS IN HUNGARY}

The present party structure of Hungary was formed by the 2010 elections, when the previously solid two-horse race was swept away by the defeat of the left-liberal pole. Two previously dominant parties (the conservative MDF, and liberal SZDSZ) did not reach the five percent parliamentary threshold, while two 'new parties' the radical nationalist Jobbik, and green-liberal Politics Can Be Different (LMP) got into the parliament. In the 2010 elections centre right Fidesz-KDNP reached a constitutional majority in the house and in the subsequent four years it was accompanied by two middle-sized parties (former governing Hungarian Socialist Party - MSZP, and Jobbik), and the small LMP in the parliament. The new electoral system of Hungary was first tested in the 2014 parliamentary elections which provided an opportunity to detect its efficiency and impact on the results of different political formations.

To begin with, it can be safely said that despite the decreasing popularity and support of the ruling Fidesz-KDNP coalition there was a great deal of stability both within the party system and the geographical embeddedness of the political parties. In order to scrutinize the spatial pattern of party-support, following the concept of Leib and Quinton (2011), we should take into account the geographical differences of settlement, socio-economic background, religion, ethnicity and language of the population. During our analysis we focus on the results of the 2014 elections in the newly established constituencies. We considered Fidesz-KDNP strongholds where the ruling conservative party-tandem received over average support. We also defined districts where the dominance of Fidesz-KDNP was less marked and another pole (either the radical nationalist Jobbik, or the left-liberal alliance) challenged the governing parties. Finally a few districts where left-liberal parties managed to gain majority could also be delimited (Figure 3.)

If we put the results of the 2014 elections in a longer perspective it can be said that the Budapest-countryside or better to say the urban-rural divide has sharpened in the voters' behaviour in Hungary after 2000. In 2006 the left wing Hungarian Socialist Party still had a geographically balanced voter support with slight urban dominance. This was practically seized by 2010 . In 2014 the left wing party (with the active support of other left-liberal opposition groups) managed to consolidate its influence in some of the urban (Budapest) constituencies, however, in the countryside the clear political winner of the 2014 elections was the radical nationalist Jobbik. The party received 20.54 percent of the vote, gaining almost 4 percent compared to 2010. In many of the countryside districts of crisis ridden Eastern Hungary, especially where the share of the Roma minority and unemployment is high the battle was not so much between left and right, but between right and far right in 2014 [7]. 


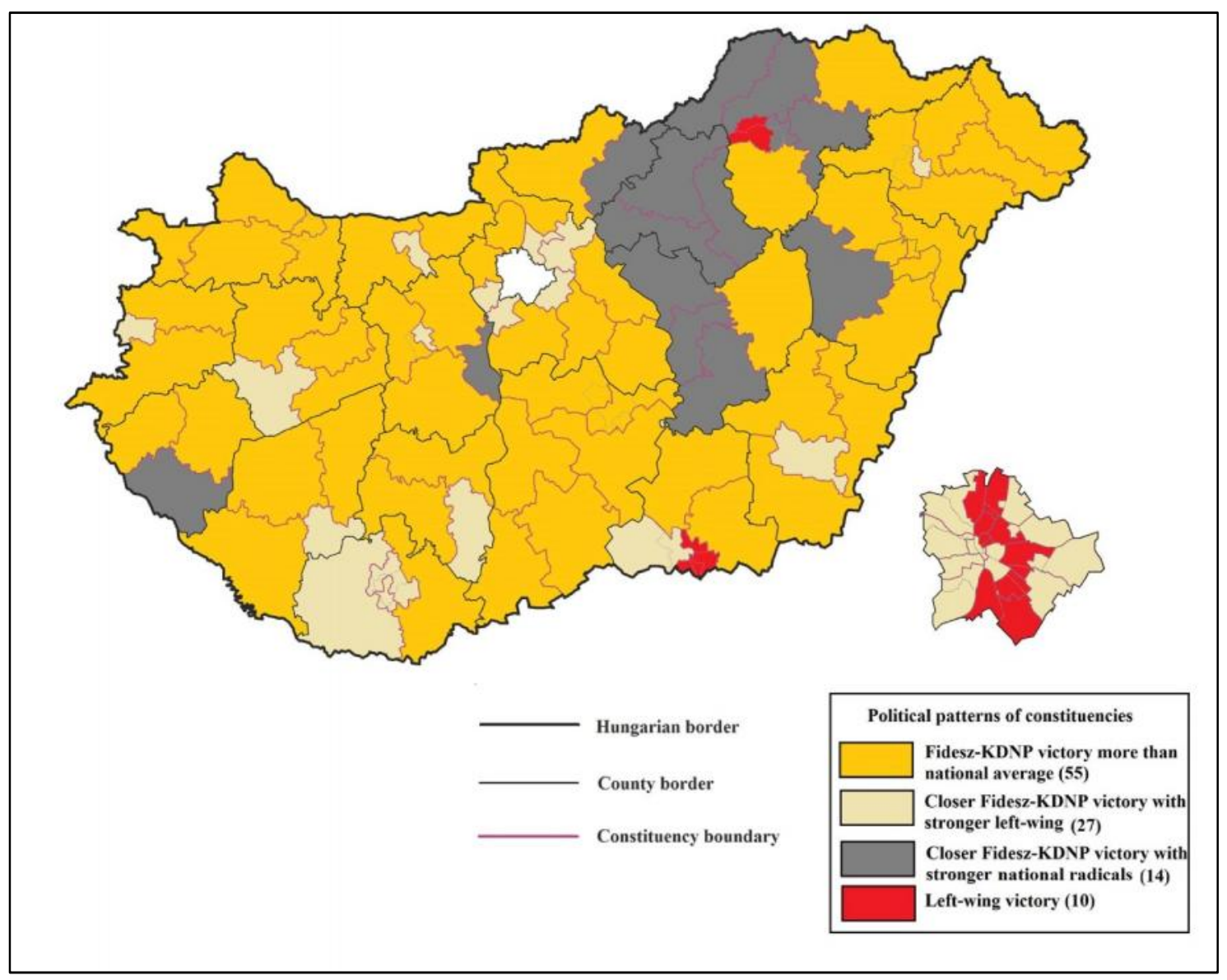

Figure 3. The Hungarian single member districts based on political attitudes, 2014

Source: Hungarian National Election Office,

Fidesz-KDNP won all but 10 of the 106 single-member districts, and in 55 with above average support (marked with orange on the map). These are predominantly countryside constituencies with rather rural character and below average turnout rates. The fourth and final party that reached the 5 percent threshold of parliamentary representation in 2014 was Politics Can Be Different (LMP), which lost slightly compared to 2010 (-2.2 percent). The LMP is a "green-liberal" party with a moderately alter-globalization agenda. Its main support base is made up of higher educated professionals in urban settings, most notably Budapest.

In the light of the 2014 election results the possible effects of the 2011 redistricting should also be evaluated. Before the elections the ruling coalition parties were accused by the opposition with politically motivated gerrymandering. It is a fact that several constituencies with former left majority were split up, for example in Budapest, while traditional strongholds of left-liberal parties in major cities (Miskolc, Pécs or Szeged) were extended by suburban settlements with conservative dominance. In both cases one can suspect that the designers of the new electoral map were influenced by electoral databases from the past. To test the degree of gerrymandering was beyond the scope of our study, but based on the 2014 results we can say, that both the spatial fragmentation as well as the high concentration of leftish (non-conservative) votes could be recorded which implies the presence of partisan gerrymandering, first time in the post-communist 
countries (i.e. gerrymandering on ethnic basis is present in the region in many different forms).

\section{CONCLUSIONS}

In this paper the geographical aspects of the new electoral system of Hungary and the results of the 2014 elections were analysed. The new electoral system was introduced by the ruling Fidesz-KDNP in two steps in 2011 and 2013 with a constitutional majority in the parliament, and no wide scale consultation about the nature of the new system or the delineation of the new electoral districts took place. Looking at sheer facts we can conclude that the Hungarian Parliament became smaller, the new electoral system simpler than the previous one, while its efficiency increased. These are the positive sides. The redrawing of district boundaries was a necessity because the territories of constituencies were not proportional and the Constitutional Court has ruled the previous law unconstitutional twice before 2010. We can also say that the new law essentially solved the constitutional problem concerning disproportional constituencies, however, only for a short term because current demographic and migration trends seriously threaten the equal population criterion, already as early as the next (2018) elections. At the same time geographical bias in the delimitation of the new electoral districts is quite obvious. An independent committee consisting of experts (e.g. geographers) in order to establish the new boundaries of constituencies would have clearly been more fortunate, yet, this was not the case under the given political circumstances.

The analysis of the 2014 pattern of voting showed that the urban-rural dichotomy has considerably increased compared to the previous elections. In the overwhelming majority of the single-member districts the ruling Fidesz-KDNP enjoyed a comfortable victory and only in some of the urban constituencies of large cities (mostly Budapest) and in Eastern Hungarian crisis ridden peripheral districts with aggregated socioeconomic problems had alternative political power any chance. In the first group of districts the left-liberal alliance, in the second the radical nationalist Jobbik. And even though Fidesz-KDNP lost more than 570,000 voters compared to the 2010 elections, a drop of 8.2 percent, given the extreme disproportionality of the new electoral system led only to a drop of only 1.3 percent of the seats.

\section{REFERENCES}

[1] Altman, M. 2002: A Bayesian approach to detecting electoral manipulation. Political Geography. 21.1. pp. 39-48.

[2] ERIKSON, S. R. 2002: Sources of partisan bias in US congressional elections an update stimulated by Ron Johnston' s essay. Political Geography. 21.1. pp. 49-54.

[3] FOSTER, B. 2013: Redistricting and the elusive ideals of representation. Political Geography. 32.1. pp.15-17.

[4]Gallagher, M. and Mitchel, P. 2005: The Politics of Electoral Systems. Oxford University Press, Oxford. 688p.

[5] Heged S G. 2007: Az Alföld 1990 és 2006 közötti választásföldrajzi sajátosságainak áttekintése. In: SzÓNOKY ANCSIN G., PÁL V. and KARANCSI Z. (szerk.): 
A határok kutatója. Magyarságkutató Tudományos Társaság, Szeged-Szabadka. pp. 123-129.

[6] JoHnstON, R. 2002: Manipulating maps and winning elections: measuring the impact of malapportionment and gerrymandering. Political Geography. 21.1. pp. 1-31.

[7] Pattie, C. and Johnston, R. 2014: 'The electors shall meet their respective states': Bias and the US Presidential Electoral College, 1962-2012. Political Geography. 40.1. pp. 35-45.

[8] KovÁCS I. 2012: Vidék az ezredfordulón, A jelenkori magyar vidéki társadalom szervezeti és hatalmi változásai. Argumentum Kiadó, Budapest. 244p.

[9] Kovács, Z. - Dingsdale, A. 1998: Whither East European democracies? The geography of the 1994 Hungarian parliamentary election. Political Geography. 17. 4. pp. 437-458.

[10] KovÁcs Z. 1993: The geography of Hungarian parliamentary elections 1990. In: O'Loughlin, J. and Wusten, H. VAN DER (eds.) The New Political Geography of Eastern Europe. Belhaven Press. London. pp. 255-273.

[11] LEIB, J. and QUINTON, N. 2011. On the Shores of the „Moribund Backwater”? : Trends in Electoral Geography Research Since 1990. In: WARF, B. and LEIB, J. (eds.): Revitalizing Electoral Geography. Ashgate Publishing Company, Burlington, pp. 9-30. [12] Martis K.C., Kovács, Z., Kovács, D. and Peter, P. 1992: The geography of the 1990 Hungarian parliamentary elections. Political Geography. 11. 3. pp. 283-305.

[13] MÉSZÁros, J., SOlYMosi, N. and SPEISER, F. 2007: Spatial distribution of political parties in Hungary 1990-2006. Political Geography. 26.7. 804-823.

[14] MoORE, T. 2002: Comments on Ron Johnston's „Manipulating maps and winning elections: measuring the impact of malapportionment and gerrymanering". Political Geography. 21.1. pp. 33-38.

[15] RaWLS, J. 1971: Theory of justice. Harvard University Press, Cambridge. 607p.

[16] WeBsteR, G. R. 2013: Reflections on current criteria to evaluate redistricting plans. Political Geography. 32.1. pp.3-14.

[17] Young, I. 1990: Justice and the Politics of Difference. NJ: Princeton University Press, Princeton. 286p.

\section{Internet sources}

[18] http://net.jogtar.hu/jr/gen/hjegy_doc.cgi?docid=A1100203.TV\&celpara=\#xcelparam (collection of existing legislation of Hungary)

[19] http://net.jogtar.hu/jr/gen/hjegy_doc.cgi?docid=A1300036.TV\&celpara=\#xcelparam (collection of existing legislation of Hungary) 